\title{
Nowe możliwości kształtowania elewacji z wykorzystaniem projektowania parametrycznego
}

\section{New possibilities for facade shaping using parametric design}

Streszczenie

Artykuł prezentuje nowe możliwości wykorzystania narzędzi do projektowania parametrycznego w edukacji architektoniczpar a tre we Znajomość potenciału przedstawionych w artykule narzedzi moż bezpośrednio przekładać sie na sposób i jakość parame trycznego projektowania architektonicznego. Przedstawiono cykl postepowania edukacyino - projektowego na przyktadzi ćwiczenia laboratoryinego realizowanego na przedmiocie Techniki BIM w Projektowaniu (I stopień I rok, semestr 02) oraz Projektowanie Parametryczne BIM (II stopień, I rok, semestr 02) prowadzonych przez Zakład Geometrii Wykreślnej. Rysunk Technicznego i Grafiki Inżynierskiej na Wydziale Architektury Politechniki Krakowskiej im. T. Kościuszki.

\section{Abstract}

In this paper new possibilities of using tools for parametric design in architectural education, as well as in design creativity on the example of an arrangement of building facades are provided. In this study the issue of the parametric creation of building facades in the BIM environment using the ArchiCAD and the Grasshopper programs is analysed. Knowledge of the potential of the tools presented in the paper may evoke a straightforward effect on the method and the quality of paramethic archiectur design. To substantiase this claim the exemplary cycle of an educational and design procedure as pat of laboratory exercises is presented. The exercises took place during the courses: BIM Techniques in Design (1st degree, 1s year, 2nd semester) and Parametric BIM Design (2nd cycle degree, Ist year, 2nd semester, optional course) carried out by the Department of Descriptive Geometry, Technical Drawing and Engineering Graphics at the Faculty of Architecture Cracow University of Technology.

Stowa kluczowe: projektowanie parametryczne,

\section{Wstep}

Dynamiczny rozwój świata w zakresie technologii i sposobów projektowania wymaga nowego podejścia do zagadnienia tworzenia obiektow architektonicznych. W szczególności dotyczy to potrzeby projektowania nowoczesnych przegród zewnętrznych dla architektury uzyteczności publicznej. Naprzeciw tym tendencjom wychodzą najnowsze możliwości jakie posiadają obecnie narzędzia do projektowania parametrycznego. Zainspirowalo to do opracowania nowego zadania laboratoryjnego dla studentow Wydziału Architektury Politechniki Krakowskiej im. T. Kosciuszki. W ramach zajęc w roku akademickim 2017/2018 z przedmiotów Techniki BIM w Projektowaniu (I stopień, I rok, semestr 02) oraz fakultetu

\section{Introduction}

The dynamic development of the world within the ology and methods of design requires chitectural objects. In particular this applies to the call for design of up-to-date building envelopes in newest the archipecture of public buildings. The tools for parametric design, come out to meet these trends. of a new laboratory exercise for students of the Faculty of Architecture Cracow University of Technology. Iy the academic year $2017 / 2018$ the issue of façad design was int the courses: BIM Techniques in Design (1st degree,

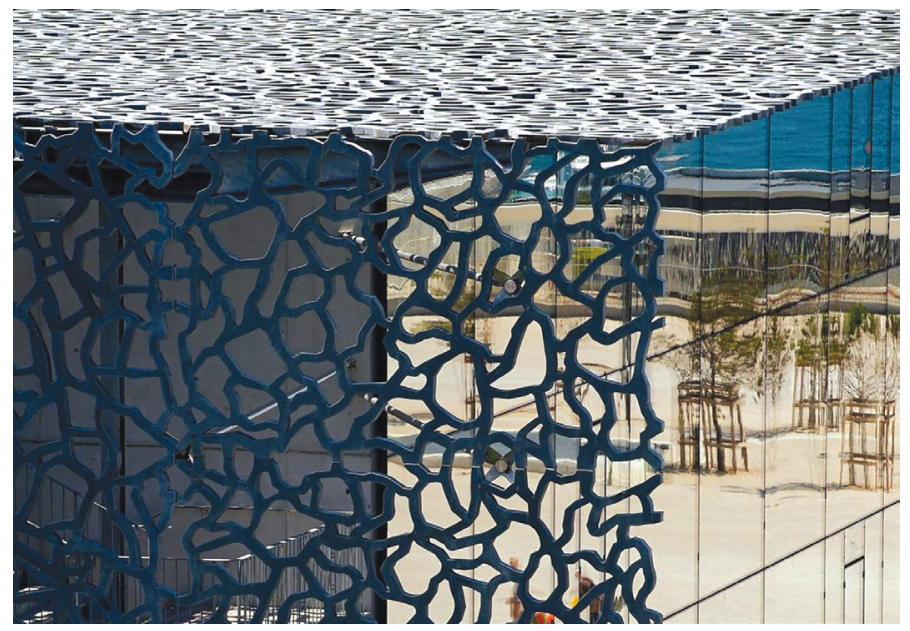

Projektowanie Parametryczne BIM (II stopień, I rok, semestr 02) pod kierunkiem dr hab. Krystyny Romaniak prof PK prowadzonych przez Zakład Geometrii Wykreślnej, Rysunku Technicznego i Grafiki Inżynierskiej wprowadzono kreowanie elewacji $w$ technologii BIM sprzeżonej z projektowaniem parametrycznym. Inspiratorami wdrożenia tego ćwiczenia do zajęć laboratoryjnych byli $\mathrm{mgr}$ inż. arch. Rafał Zieliński oraz mgr inż. arch. Maciej Wójtowicz, do których dołączyli dr inż. mgr inż. arch. Maciej Wojtowicz, do których dolączyli dr inż. projektowe stało sie podstawa przedstawionego poniżej sposobu kreowania elewacji

Współcześnie wiele realizacji architektonicznych osłoniętych jest nowoczesną, wielowarstwową, a takze transparentna skórą. Zrywa ona z standardowym myśleniem o elewacj $w$ kategorii kompozycji z rozmieszczonych okien na rzecz swobodnej aranżacji róznorodnych materialów elewacynych i przeszkleń. Jeszcze większy potencjał aranżacji w tym aspekcie mają obiekty, których funkcja nie wymaga dostępu do naturalnego światta.

Architekci w dążeniu do projektowania unikalnych obiektów o własnej tożsamości stale poszukuja oryginalnych wzorów nowatorskich materiatów. W dalszym ciagu niewyeksploatowanym zasobem nowych form dla ich poszukiwań, o czesto Weometrycznym chakterze, pozostaje projektowanis rametrycze Stanowi ono obszar inspiraij dla wzornicto plastyi, a takze formowa obsia metode projektowania.

\section{Projektowanie parametryczne}

Zagadnienie projektowania parametrycznego architektury jest szeroko obecne $w$ literaturze światowej oraz coraz szerzej w polskiej. Powyższą tematyke poruszono przykładowo w publikacji John'a Maeda Design By Numbers', Daniela Davis'a Modelled on Software Engineering: Flexible Parametric Models in the Practice of Architecture ${ }^{2}$, czy Arturo Tedeschi AAD Algorithms Aided Design. Parametric Strategies using _-Algorithms Aided Design. Parame to między W -algorytmiczne projektowanie architektury4, Krystyny Ja-

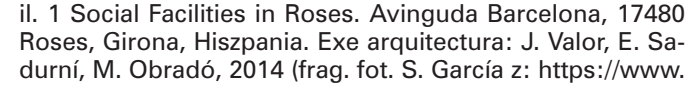
archdaily.com/773060/social-facilities-in-roses-exe-arquit ectura/55dd2883e58ece6d4 10000of3-social-facilities-in-ro-
ses-exe-arquitectura-photo (dostepp: 07-07-2018)) Roses, Girona, Spain. Exe arquitectura: J. Valor, E. Sadurn M. Obradó, 2014 ( photography fragment of S. García from
https://www.archdaily.com/773006/social-facilities-in-roses-

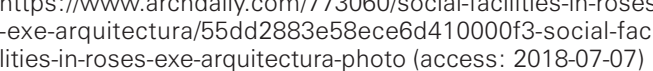

st year, 2nd semester) and Parametric BIM Design 2nd cycle degree, 1st year, 2nd semester, optional course) under the guidance of Ph.D. Krystyna Romaniak, professor at CUT, conducted by the Department of Descriptive Geometry, Technical Drawing this training for Graphatory The Techlestation of inspiration by Msc. Arch. Rafat Zieliński, and Msc. Arch. Maciej Wójtowicz, later joined by PhD. Arch. Faid Nassery, and Eng. Arch. Paweł Sikorski. The design task became the groundwork for the manner of facade creation which shall be set out below.

covered with a modern, multi-layered, as well as transparent overlay. It breaks with the traditional standpoint where the facade is perceived as a composition of windows' deployment for and glazings In this matter objects whose function does not require access to a natural light have even a greater potential.

In the quest for designing unique objects equipped with their own identity architects constantly search metric design remains still an inexhaustibls . Parafor their exploration of new forms, often of geometric features. It is proclaimed to be a land of inspiration for design, visual arts, as well as a creation of architecture. for this reason architects increasing

2. Parametric design

The matter of parametric architectural design is widely present in foreign and increasingly Polish literature of the subject. To mention few examples, by John ing: Flexible Parametric Models in the Practice of Architecture by Daniel Davis ${ }^{2}$ or AAD_Algorithms Aided Design. Parametric Strategies Using GrassAided Derign. Para Tedeschr. in Pollsh literature of von: Parametryczno-algorytmiczne projektowani $O$ projektowaniu $w$ dobie narzędzi cyfrowych Stan aktualny i perspektywy rozwoju by Krystyin Januszhy is pers and also he papers. Systemynarzeddzia generatywne, projektowaniu architekcznicznym? Czym jest pro- 


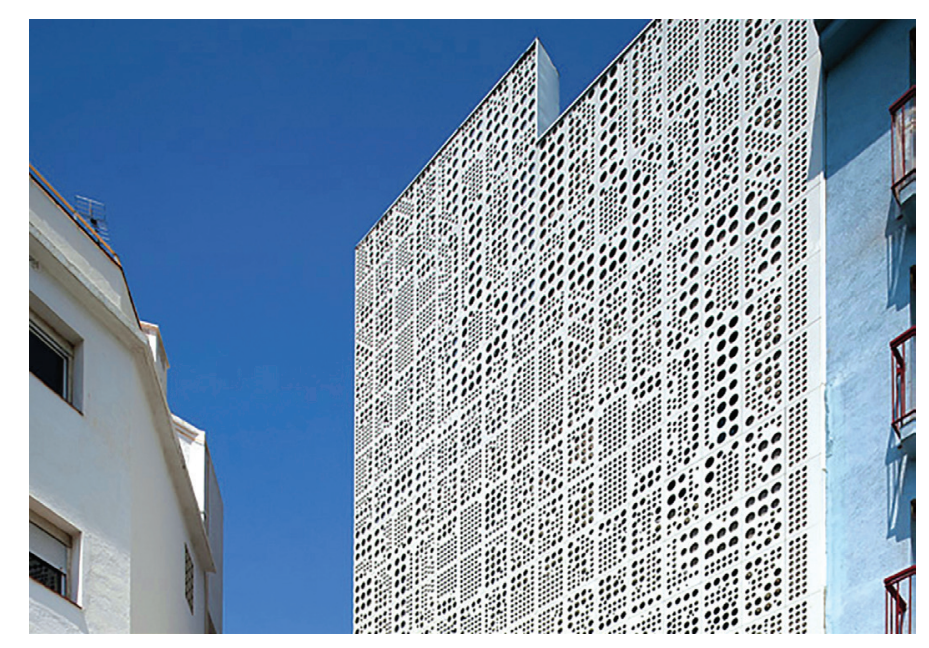

nuszkiewicz $O$ projektowaniu $w$ dobie narzędzi cyfrowych. Stan aktualny i perspektywy rozwojus a takì $w$ artykułach Krystyny Januszkiewicz Systemy i narzędzia generatywne ${ }^{6}$, Projektowanie parametryczne oraz parametryczne narzędzia cyfrowe w projektowaniu architektonicznym ${ }^{7}$, Czym jest projektowanie parametryczne? ${ }^{\text {? }}$. Powyższą problematykę można znaleźć również na portalach internetowych przykładowo takich jak Projektowanie Parametryczne - architektura w nowym wydaniu ${ }^{9}$ czy też blogach internetowych prowadzonych przez specjalistów - Blog Daniela Davis'a ${ }^{10}$

Definiując projektowanie parametryczne jest to proces, w którym za pomocą modelu zawierającego relacje między jego elementami poszukuje się własciwych wartości parametrów opisujących te związki. W zależności od ilości parametrów, jak również liczby charakteryzowanych wymiarów, możemy mieć do czynienia z bardziej lub mniej złożonym zagadnieniem. Dla tego samego modelu inny zestaw wartości będzie np. opisywał stan maksymalnej objętości, a inny stan najlepszej relacji objętości do powierzchni. Taki model cyfrowy odpowiednio zaprogramowany może być szybko przetwarzany przez komputer. Maszyna obliczeniowa może przeprowadzać jego analizy, transformacje i optymalizacje. Innymi słowy przetwarzać informacje zawarta w tym modelu. Metoda ta jest cenna z co najmniej trzech powodów. Po pierwsze daje mozliwość wariantowani konopodi projektowej dzięki elastyczno w projektowanej geometrii. gorytmy i skrypty moga zostac ponownie wykorzystane. Po trzecie umozilw ma dosc trafne analizy wplyw modelu na

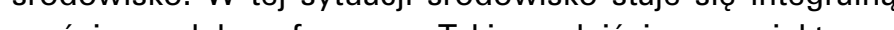
czesscią modelu cyrrowego. Takie podejscie w projektowaniu zostalo zaanektowane do swiata architektury z scisłych dziedzin inżynierskich. Transfer tej metodologii wynika z faktu uproszczenia i upowszechnienia się narzędzi do budowania algorytmów i programowania. Zaowocowat on wieloma realizacjami, takimi jak fasada domu handlowego Weltstadthaus (1999-2005) w Kolonii projektu Renzo Piano"1, Yas Island Marina Hotel (2007-2009) przy torze wyścigowym Formuły 1 w Abu Dhabi projektu Hani Rashid i Lise Anne Couture z Asymptote ${ }^{12}$

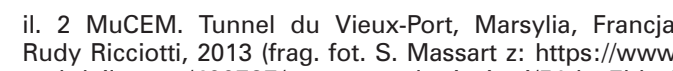

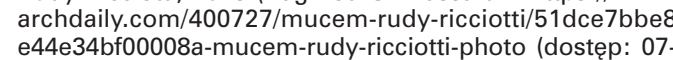

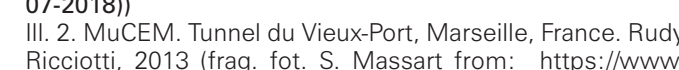

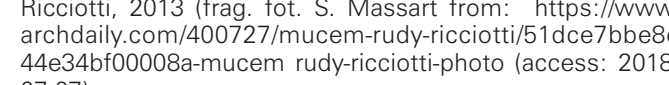
07-07)

jektowanie parametryczne? ${ }^{?}$ all published by Krystyna Januszkiewicz. The issue set out above one can na Januszkiewicz. The issue set out above one can Parametryczne- architektura w nowym wydaniu ${ }^{9}$ to name an example, or Internet blogs run by specialists - such as the blog of Daniel Davis

To define a parametric design one has to take into model containing their mutual relations and by the eters describing this dependency and a process during which appropriate values of those parameters are sought. One may have to deal with a rather complex or rather simple issue, depending on the number of As an example - for one and the same model on set of values will describe the state of a maximum volume, while another one the state of an optimised relation between a volume and a surface. Such a digital model can then be processed quickly using a computer if properly programmed. The computing an optimisation. In other words - can process infomation included in this model. There are three main reasons which make this method profitable. First of all it gives the possibility of variation within the design concept according to its flexibility and ease of amending the designed geometry. Secondly algo-
rithms and scripts once developed can be reused in rithms and scripts once developed can be reused in
another circumstances. Last but not least -it enables quite accurate analyses of an impact of the model on an environment. Thus an environment becomes an integral part of the digital model. This approach, now naturally present in the world of architectural design, comes from the engineering science. The possibility that building and programming tools for algorithm became more and more simple and popular. The facade of Weltstadthaus department store in Cologne designed by Renzo Piano (1999-2005)"1, Yas Islan Marina Hotel at the Abu Dhabi Formula One racetrack designed by Hani Rashid and Lise Anne Couture of many realisations that resulted from this idea. Three main groups of architectural applications can be distinguished concerning the intensity in using these tools and their impact on the architectura forms. To the first one belong all those where com tectural form and design, but rather serves to verify it

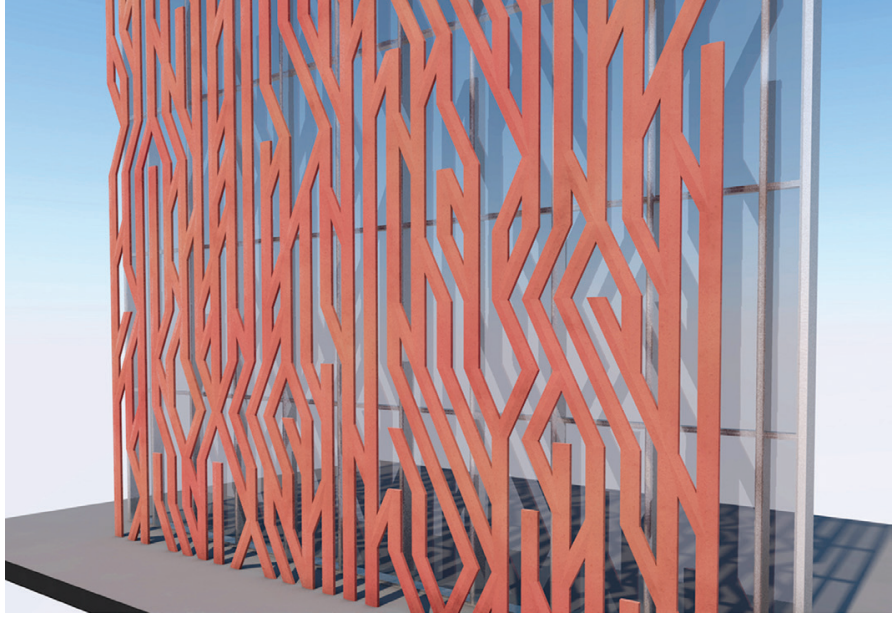

Intensywność zastosowania tych narzędzi i ich wpływ na formę architektoniczną można podzielić na trzy główne grupy

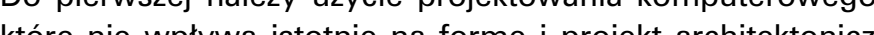
kore nie wplywa istotnie na formę i projekt architektoniczny, a raczej służy jego weryfikacji (np. czy spełnia określone wymogi energochionnosci, czy przewidzlana konstrukcja jest wykonalna). Zmiany w samej architekturze dokonują się n drodze konsultacji i poszukiwania konsensusu z wynikam analiz komputerowych. Kolejna grupe stanowi zastosowani projektowania parametrycznego w celu wykorzystania wynikow do optymalizacji i redukcji kosztow przedsięwzięcia. Poszukiwane są najlepsze rozwiązania technologiczne do osiągnięcia zamierzonych celów. W takim przypadku zdarza się, ze forma architektoniczna podporządkowana jest logice inżynierskiej, a wręcz staje sie jej manifestacja. Trzecim przypadkiem jest wykorzystanie narzędzi komputerowych w celu opracowywaniu formy i wyrazu architektonicznego. Można mieć w tym wypadku do czynienia z sytuacja, gdzie modelowanie komputerowe służy do zapisu i przetwarzania skomplikowanych geometrii, których opisywanie ręczne byłoby karkołomnym zadaniem. Pewnym wariantem tego podejścia jest proces nazwany form-finding Polega on na całkowitym oparciu sie na algorytmach i generowanych przez nie formach przestrzennych. W tym podeśsiu dly architektów otwierach nowy wyitkowo obszerny wachlarz form, stylistyk i geor sie trii bazujacych na różnery (a) szerokiego spektrum algorytmów matematycznych ${ }^{13}$.

\section{Technologia BIM}

Kolejnym ważnym elementem w tworzeniu zaawansowanych elewacji jest wykorzystanie technologii BIM (ang. Building Information Modeling). Tej tematyce poświęconych jest bardzo wiele publikacji, które można podzielić na dwa główne nurty omawiające całościowo technologię BIM oraz prezentujace wyłącznie sposoby obsługi programów komputerowych wspomagających projektowanie w tej technologii. Do pierwszego nurtu należą przykładowo takie publikacje jak: Lincoln Forbes'a Information and Communication Technology/Building Information Modeling ${ }^{14}$, Brada Hardina i Dava McCool'a
II. 3 Wizualizacja systemu elewacyjnego zaprojektowanego
parametrycznie lautor: inż. arch. Paweet Sikorski, prowadzacy zajecia: mgr inż. arch. Szymon Filipowski, mgr inż. arch.
Michat Nessel, mgr inż. arch. Maciej Wójtowicz, mgr inż. arch. Rafat Zieliński)
III. 3. Visualisation of the parametrically designed facade
system ( Author: Eng. Arch. Pawet Sikorski, lecturer: MSC.
Arch. SYymon system (Author: Eng. Arch. Pawet Sikorski, lecturer: MSc.
Arch. Szymon Filipowski, MSc. Arch. Michat Nessel, MSc
Arch. Maciej Wojtowicz, MSc. Arch. Rafat Zielinskil)

(e.g. whether it meets certain energy-consumption requirements or if planned construction is feasible). Changes in the architectural structure as it is are car-

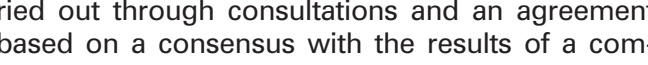
puter analysis. Realisations from another group are in order to costs. In this case sometimes it happens that architectural form is subordinated to engineering logic and even becomes its manifestation itself. The third case is connected with the use of computer tools
to develop an architectural form and expression. Here one may deal with a situation when computer modelling serves to write and process complicated geometries for which a manual description would be a harebrained task. A process called form-finding is a certain variation of this approach. It consists in ated by them. In this approach a wide panoply of forms, styles and geometries on a variety of algorithm opens up in front of architects. Those possibilities can draw inspiration from the natural world, i.e. biomimetics, emergences, chaos theory, a wid

\section{BIM Technology}

While creating an advanced facade one may take into account another important element, namely the use of BIM (Building Information Modelling publications which may be classified into two main trends: the ones discussing the BIM technolog as a whole and the ones presenting only some of the ways to use computer programs supporting design within this technology. Publications tha Communication Technology/Building Information Modeling by Lincoln Forbes ${ }^{14}$ and BIM and Construction Management by Dave McCool15; and also in polish: BIM Innowacyjna technologia w bu downictwie by Andrzej Tomana $a^{16}$ and one of the tyce Standardy wdrożenia case study by Dariusz Kasznia, Jacek Magiera and Paweł Wierzowiecki ${ }^{17}$ To complete the list one has to mention books containing basic knowledge related to work in the ArchiCAD, which is one of the programs employprojektowania BIM by Rafat Ślekek', Archicad 21 

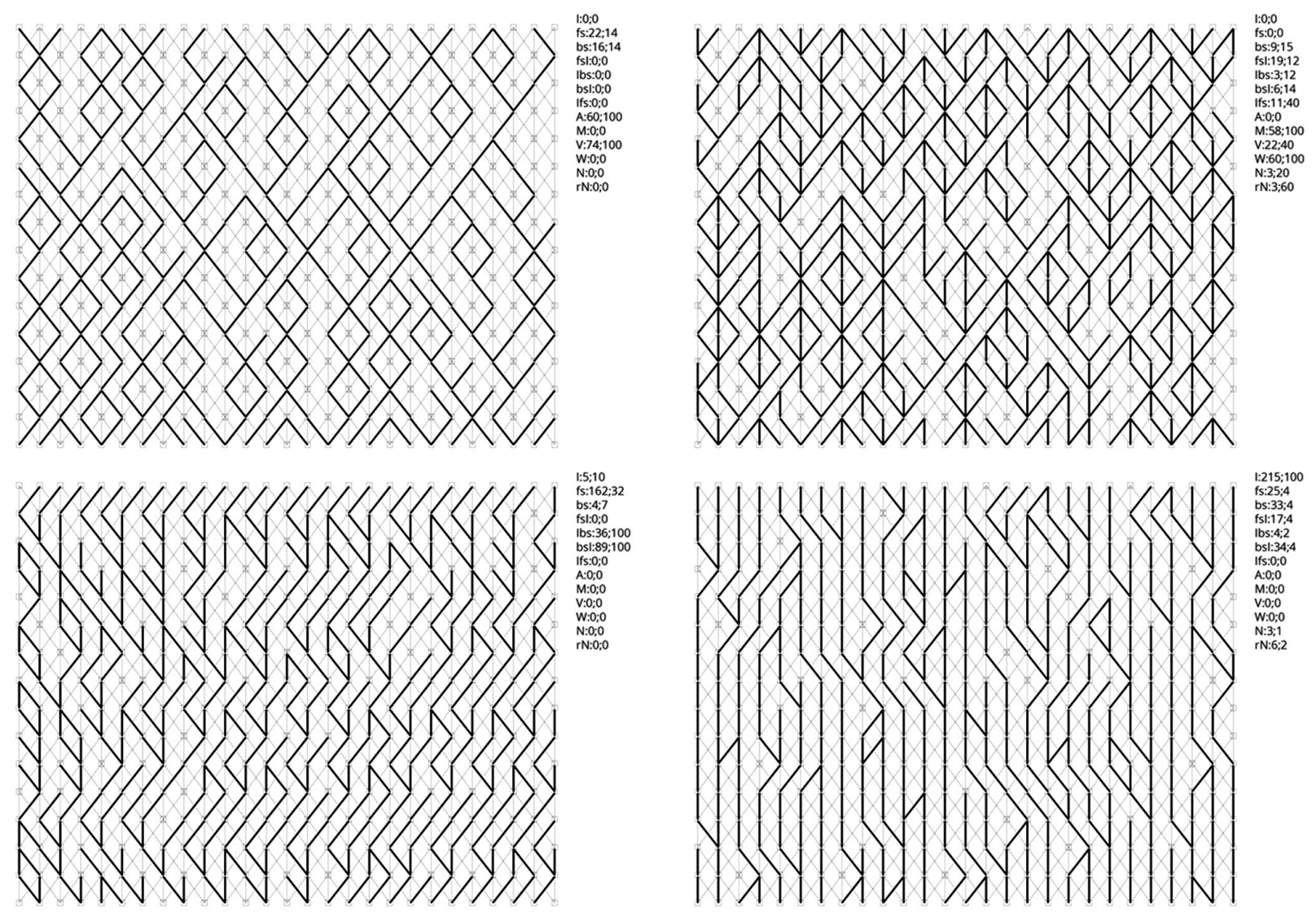

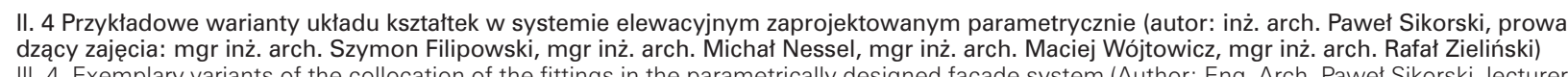

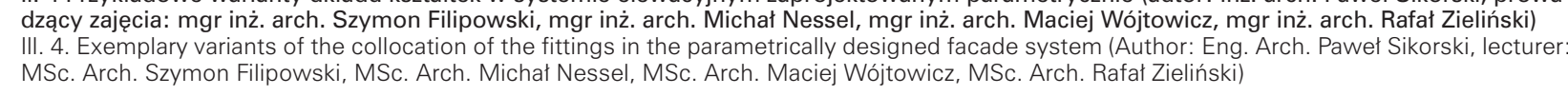

BIM and Construction Management ${ }^{15}$, Andrzeja Tomany BIM Innowacyjna technologia w budownictwie ${ }^{16}$, czy jedna z najnowszych polskich książek Dariusza Kaszni, Jacka Magiery i Pawła Wierzowieckiego BIM w praktyce Standardy wdro-
i i Pawła Wierzowieckiego BIM w praktyce Standardy wdro-
zenia case study ${ }^{17}$. Natomiast podstawy wiedzy związanej zenia case study" . Natomiast podstawy wiedzy związanej
z prachiCADzie, będącym jednym programów wykorzyz pracą ArchiCADzie, będącym jednym programów wykorzy-
stujących technologie BIM można znaleźć w takich książkach jak: Rafała Ślęka ArchiCAD. Wprowadzenie do projektowania Jak: Ris , Bernharda Bindera Archicad 21 BIM-Modellierung und $B M^{18}$, Bernharda Bindera Archicad 21 BIM-Modellierung und
Dokumentation $^{19}$. Powyższą tematykę prezentuje także wieDokumentation ${ }^{19}$. Powyższą tematykę prezentuje także wie-
le źródeł internetowych, przykładowo blog bimblog.p pl20 oraz GRAPHISOFT BIM Curriculum ${ }^{21}$.

Model BIM jest to zbiór wirtualnych informacji tworzący kompletny opis budynku. Stanowi on bazę danych, która $\mathrm{w}$ trakcie projektowania jest na bieżąco uzupełniana i poszerzana ${ }^{22}$. Ta forma podejścia do procesu budowlanego wynika z ogromnego rozwoju technik informatycznych i ich wpływu na wszystkie dziedziny zycia oraz działalności człowieka. Postęp w tej dziedzinie spowodował rozwinięcie narzędzi do analizy $i$ przetwarzania danych zgromadzonych $w$ trakcie tego procesu. Dane przechowywane $w$ cyfrowej formie zapisu dotyczą: geometrii obiektu, użytych materiałów, charakterystyki energetycznej, właściwości konstrukcji, przebiegu i części składowych wszystkich instalacji, kosztów realizacji, dodatkowych cech wyposażenia obiektu, etapów realizacji ożarowego itp.. Innymi słowy wszelkich informacji niezbeednych w całym cyklu zycia obiektu od realizacji, poprzez eksploatacje, aż do utylizacji. Mode taki umożliwia tworzenie wizualizacji, generowanie rysunków do fabrykacji, rewizje zgodności elementów, wyszukiwanie kolizji przestrzennych, kosztorysowanie oraz opracowywanie harmonogramów budowy. Ze wzgledu na to że zmiany do konywane przez jodno osobe automatycznie dostepne do reszty zespołu i w pow mentacja jest ciagle aktualna.

Poczatki technologii BIM siegaja końca lat 80' XX wieku23. Odwieku². Odchodzenie architektów od deski kreślarskiej to był dość dług proces, zWażwszy na to, że pierwsze wzmianki o możliwości

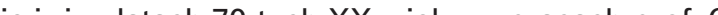
się już W latach 7O

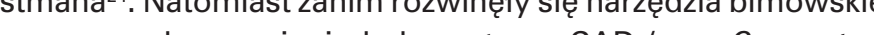
w powszechnym uzyciu były systemy CAD (ang. Computer-aided design). Wspomagaty one proces tworzenia budynk $w$ ten sposób, ze zastępowały deskę kreślarską i umożliwiaty tworzenie rysunków i dokumentacji technicznej w postaci cyfrowego modelu geometrycznego. Dalszą konsekwencja rozwoju tego typu systemów było wprowadzenie trzeciego wymiaru do modelu, co umozliwilo operowanie na bryłach. Technologia ta zyskała nazwę Object CAD Technology. Umoż liwiała ona już automatyczne generowanie płaskich rysunków na podstawie trójwymiarowych kształtów. Dalszy rozwój trendów i oprogramowania zmierzał już w kierunku opracowania technologii BIM. Świadczy o tym fakt, że we wczesnych latach różne firmy pracowały nad tym zagadnieniem pod różnym nazwami. I tak Graphisoft tworzył "Virtual Building". Bentley Systems opracowywat "Integrated Project Models", a Autodesk i Vectorworks "Building Information Modeling". Z czasem ugruntował sie termin BIM, a cyfrowy zapis budynku doczekał sie standardu IFC (ang. Industry Foundation Classes). Obecnie prowadzana jest standaryzacja OPEN BIM która ma rozwiazać probzo zwiazane z koordynacia przeptywu informacii miedzy partnerami i uniezależnia procesu tywu inmodelu od marki wykorzystywanego oprogramowania.

4. Projektowanie parametryczne elewacji - oprogramowanie Podstawową przesłanką opracowania ćwiczenia laboratoryjnego polegającego na tworzenu elewacji z użyciem projektowania paramerycznego byla niedawno wprowadzon wspolpraca pomiędzy programem ARCHCAD (srodowisko BIM), a program GRASSHOPPER (projektowanie parametryczne). Do tej pory osobno byly wykonywane cwiczeni laboratoryjne $z$ projektowania parametrycznego, a osobno $z$ pracy $w$ technologii BIM. Do projektowania parametrycznego wykorzystywano następujące oprogramowanie: RHINOCEROS - rozbudowany modeler 3D wykorzystujący między innymi krzywe NURBS (ang. Non-Uniform Rational B-Spline) oraz GRASSHOPPER - dodatek do RHINOCEROS oferujący wizualny język programowania umożliwiający skryptowanie zależności geometrycznych. Stan ten zmienit plugin Grasshopper ARCHICAD Live Connection ${ }^{25}$, który w prosty sposób umozliwia transfer geometrii z srodowiska end of the $1980^{\prime} \mathrm{s}^{23}$. Despite the fact that mentions about the possibility of building definition via it dign 1970 's in the eared for the first time already man 24, the architects' departure from the drawing board was quite an extended process. However CAD (i.e. computer-aided design) systems had been widely used even before the BIM tools were developed. By that time those systems already in board they enabled the creation of technical drawing and documentation in the form of a geometric digital model. A further step of the development of hose systems was the implementation of three geometry manipution. This technique was called Object CAD Technology. It enabled automatic generation of flat technical drawings based on threedimensional shapes. Further evolution of trends and a software was already heading towards to understood in the light of the fact that in the early years the same issue was under development by various companies and under different names: Graphisoft created "Virtual Building", Bentley System developed "Integrated Project Models",
Autodesk and Vectorworks produced "Building Information Modeling". As time went by the term BIM was forged and IFC (i.e. Industry Foundation Classes) was invented to standardise a digital form of a description of a building. At the moment OPEN BIM standardisation is being carried out. It is dination of information flow between partners and to make the process of model creation independent of the brand of a software used.

4. Parametric design of a facade - the software The basic premise for mapping out the laboratory metric design was recently implemented software compatibility between the ArchiCAD (BIM environment) and the Grasshopper (parametric design). Thus far laboratory exercises on parametric deogy were carried out separately. For parametric
design following software was used: Rhinoceros - an extended 3D modeler that uses, among
others, NURBS (Non-Uniform Rational B-Spline) others, NURBS (Non-Uniform Rational B-Spline)
curves; Grasshopper - a Rhinoceros add-on concurves; Grasshopper - a Rhinoceros add-on con-
taining a visual programming language which enables scripting of geometric relations. Facts are not the same since Grasshopper ArchiCAD Live Connection plug-in25, which enables to easily transfer a geometry from Rhinoceros-Grasshopper environment into the ArchicAD 21 software, environment due to its main advantage $i$ i.e, the use of a visual programming language. In simple terms it consists of a graphical and a symbolical representation in the form of components/blocks: data, the second ones to operations that one can perform on them. By combining appropriate components/blocks one can build a script that reflects the relations between its parametrically described components. There are several cases when the application of this system of facade design may be
a benefit. It may serve: to search for new form and attractive design (form-finding); to optimise 
RHINOCEROS-GRASSHOPPER do programu ARCHICAD given problem (e.g. to find the smallest material 21. Najistotniejszym elementem $\mathrm{w}$ tym zestawie jest środo- consumption while shading the interior); to repwisko Grasshopper. Cechuje je wykorzystanie wizualnego resent a complex and highly individualised geomjęzyka programowania. Składa się on w uproszczeniu z graficznej i symbolicznej reprezentacji w postaci komponentów/ klocków - po pierwsze geometrycznych danych - po drugie operacji, które można na nich wykonać. Zestawiając ze sobą odpowiednie komponenty/klocki buduje się skrypt odzwierciedlający relacje między elementami opisane za pomocą parametrów. Wykorzystanie tego systemu przy projektowaniu elewacji może mieć zastosowanie w kilku przypadkach. Po-

II. 6 Algorytm z programu Grasshopper sterujacy rozmieszczania ksztattek w projektowanym systemie elewacyjnym (autor: inż. arch. Pawet
Sikorski, prowadzący zajeccia: mgr inż. arch. Szzymon Filipowski, mgr inż. arch. Michat Nessel, mgr inż. arch. Maciej Wójtowicz, mgr inż. arch. Rafat Zielilíski)
III. 6. The Grasshopper program controlling the collocation of fittings in the designed facade system (Author: Eng. Arch. Pawet Sikorski, lecturer
MSc. Arch. Szzymon Filipowski, MSc. Arch. Michat Nessel, MSc. Arch. Maciej Wóitowicz, MSc. Arch. Rafat Zielinskil)

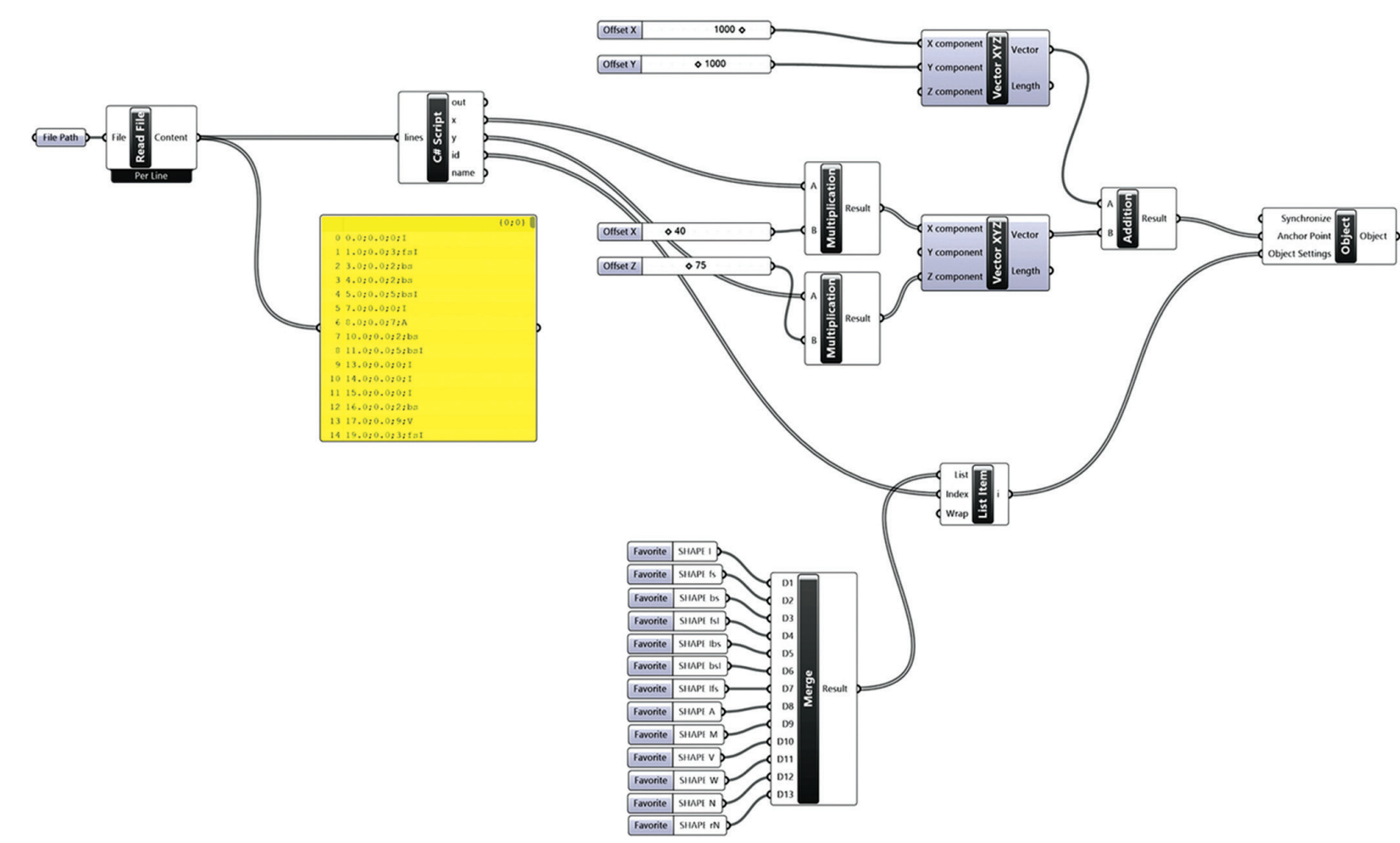

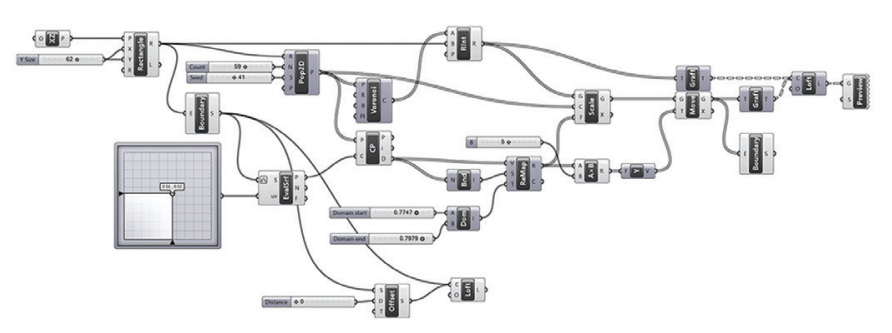

służyć on może do poszukiwania nowych form i atrakcyjnego wzornictwa (form-finding), do optymalizacji zdefiniowanego problemu (np. najmniejsze zuzycie materiału przy jednoczesnym zacienienu wętza) lub jako zapis zlożonej zindywidualizowanej geometrii. Często w projektowanych elewacjach te trzy zagadnienia występują równocześnie ${ }^{26}$.

Projektowanie parametryczne elewacji - przykłady realizacji. Jedną z inspiracji dla poniżej opisanego cyklu postępowani edukacyjno - projektowego stały się istniejące już realizacje architektoniczne, w których można zaobserwować możliwosci ksztattowania elewacji budynku w oparciu o projektowanie parametryczne. W celu zilustrowania studentom powyż szego potencjału, wybrano przykłady, które zachowują prosta bryłę, a szczególny wyraz architektoniczny uzyskiwany jes przez samo ksztaltowanie fasad.

Pierwszym z nich jest budynek administracyjny (Social Facilities) powstały w hiszpańskim mieście Roses na obszarze Kataloniii27. Projekt pracowni Exe arquitectura (zespót: Jaume Valor. Elisabeth Sadurní, Marc Obradó) cechuje wentylowan elewacja z perforowanych ptyt z polimerobetonu (il.1). Elewacja powstala $z$ kompozycji skła pajcej sez 24 typów plyt. Każdy z nich posiada inny wzór utworzony z szeregu okraKazch z nich pos o rózinch średnicach. Kolejnym przyktadem

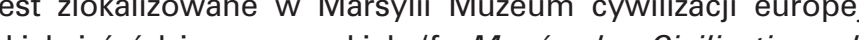
I'Europe et de la Merditerrane - MUCEM). Zaprojektow de KE zrealizowany w 2013 roku zwraca szczególną uwage swoja charaktenystyczna scianą ostonową wykonaną z ażurowej świetlistych odbić powierzchni morza ${ }^{28}$. Następny przykład
11. 7 Ćwiczenie laboratoryjne z predmiotu Projektowanie
parametrycze $B M M$ (autorzy: inżz arch. Jan Brożek, inż. arch. Łukasz Gunia, prowadzacy zajecia: prowadzący zajecia: mgr inzz. arch. Szymon Fili owski, mgr inzz. arch. Micha
Nessel, mgr inz. arch. Maciej Wójtowicz, mgr inz. arch. Ra-

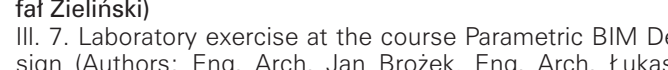
sign (Authors: Eng. Arch. Jan Brozek, Eng. Arch. tukasz
Gunia, lecturer: MSc. Arch. Szzymon Filipowski, MSc. Arch Michat Nessel, MSc. Arch. Maciej Wójtowicz, MSc. Arch.
Rafat Zielinski)

to illustrate the potential mentioned above to the students the examples were selected which can the exterior shell and the particular architectura expression coming solely from the shaping of its acade.

irst of those to be mentioned is the administrative ish city of Rosas in the region of Catalonia ${ }^{27}$. The building is based on the plans designed by the arhitecture office Exe Arquitectura (team consists It is notable for its ventilated facade Marc Obradól. position consisting of twenty four different types of perforated polymer concrete panels (Fig. 1). Each of them distinguishes itself due to unique patter created from a series of round apertures of differMuseum of European and Mediterranean Civilisations located in Marseille (fr. MuCEM; Musée des Civilisations de l'Europe et de la Méditerranée) which was designed by the architect Rudy Ricciot (Fig. 2). The building constructed in 2013 is spe openwork concrete structure. Concrete grid pattern conjures up the luminous reflections of the sea surface ${ }^{28}$. The facade of the next example evoked is arranged distinctly when compared to the previous chitects project completed in 2012 ind buit in the industrial district of Singapore. The facade of the building was accomplished according to a clearly comprehensible principle of geometrical relations Thus as the height of the subsequent horizontal dbecome more inclined and shortened. The facade combines protection from an excessive sunlight with the view opening on the foreground of the building ${ }^{22}$. 

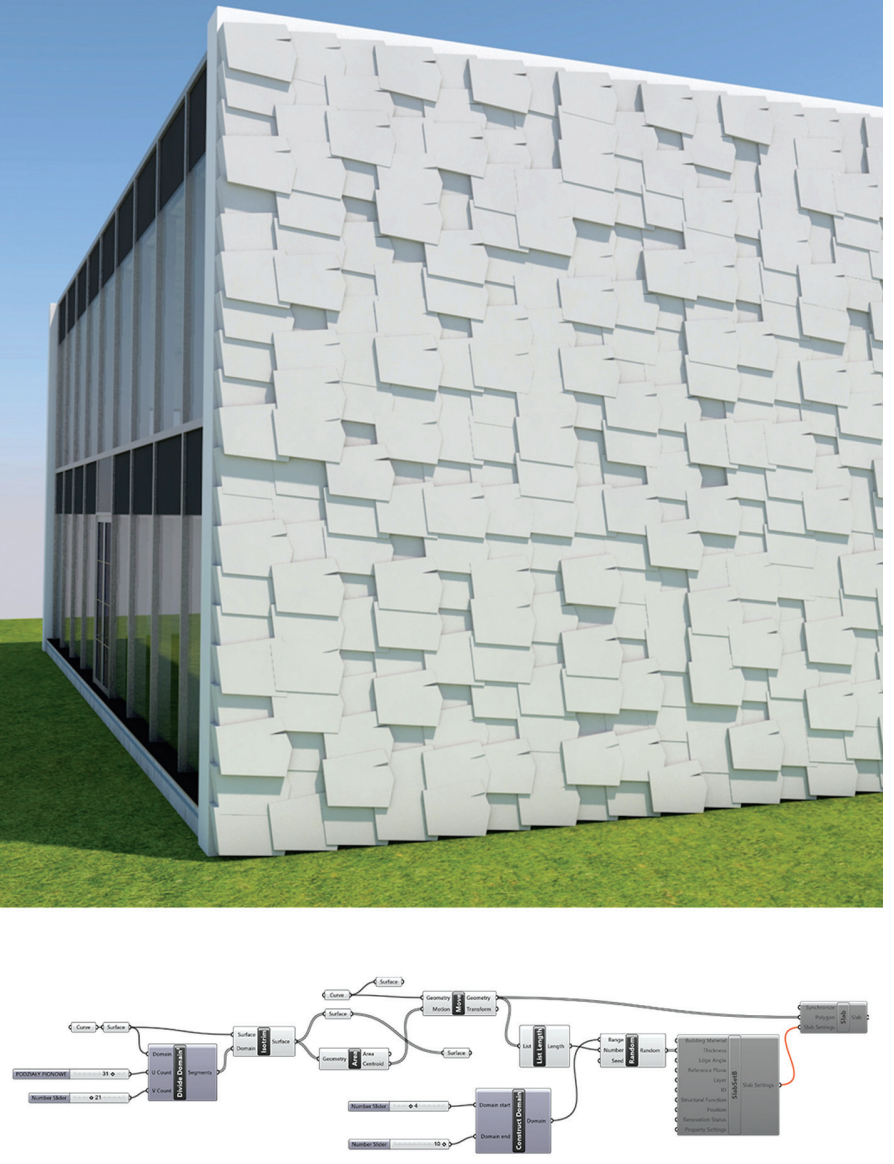

ma w odmienny sposób od powyższych zaaranżowaną fasadę. Budynek A Simple Factory Building ukończony w 2012 roku projektu Ayra Architects zbudowany został w przemysłowej części Singapuru. Elewacja obiektu została utworzona z użyciem bardzo czytelnej zasady powiązań geometrycznych i tak wraz z zmniejszaniem się wysokości kolejnych podziatów poziomych, ulegają przechyleniu i skróceniu wertykalne elementy zacieniające. Fasada ta łączy w sobie ochronę przed nadmiernym nasłonecznieniem z otwarciem widoku na przedpole budynku ${ }^{29}$

\section{Projektowanie parametryczne elewacji - metodyka}

ady projektów studenckich

W ramach ćwiczenia laboratoryjnego z przedmiotu Techniki BIM w Projektowaniu zastosowano następujący cykl edukacyjno - projektowy elewacji w oparciu o projektowanie parametryczne. Na pierwszych zajęciach zaprezentowano obsługę interfejsu programu Grasshopper oraz zademonstrowano 3 przykładowe skrypty w Grasshopperze mogące posłużyć do ksztattowania elewacji. Na kolejnych zajeciach zadaniem studentów było dostosowanie jednego z zademonstrowanych wcześniej przykłám skrytów do potrzen swowa-

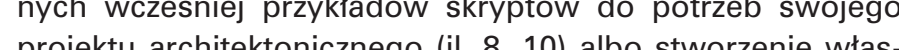
nego roz a nego rozwazan paratiast BIM po kilk spotkariach szczegótowo objániejacy proBu po kiku spotkaniach szczegolowo objosiajacych pro-

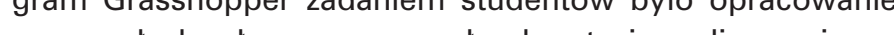
w zespolach wlasnego pomysłu skryptu i zrealizowanie go w ramach pracy semestralnej (il. 3, 7).

Zrealizowana wramach fakultetu Projektowanie parametryczne $B I M$ elewacja obiektu użyteczności publicznej autorstwa dzący zajęcia: dr inż. arch. Farid Nassery, współpraca: inż III. 8. Laboratory exercise in Design (Author: Katarzyna Żyszczyńska, lecturer: dr in
arch. Farid Nassery, wspótpraca: inz arch. Pawet Sikorksi

5. Parametric design of a facade - methodology of The following cycle of procedures concerning educational aspects and parametric design of facades was implemented as a part of the laboratory exercises during the course BIM Design Techniques. interface of the Grasshopper and three exe use the Grasshopper scripts applicable for facade shaping were demonstrated. In the following classes the task for the students was to adapt one of the ex their own architectural projects (Fig 8,10 ) or to invent own architectural parametric solution for the creation of a facade (Fig. 9). Whereas during the optional course Parametric BIM Design, after few classes devoted to specify in details how to use the into teams and the task for each of the team was to develop their own script ideas and to realise them as a midterm project (Fig. 3,7 .

The facade of a public building by Pawet Sikorski was accomplished during the classes of the course Parametric BIM Design and it mainly represents
the form-finding issue (Fig. 3-6). The implementation of the system collocating the facade fitting was dependent on the creation of an algorithm that would fill the matrix of possible connections. Aduses the Processing programmings this example shape of the fitting and frequency of its occurrence were governed by the parameters whose modifcation resulted in generating of series of diversiGred arrangements (ing. 4). The environment of the The first script generated the solid shape of the fittings and then it transferred them to the ArchiCAD program where they were saved as GDL objects $x=x^{2}$

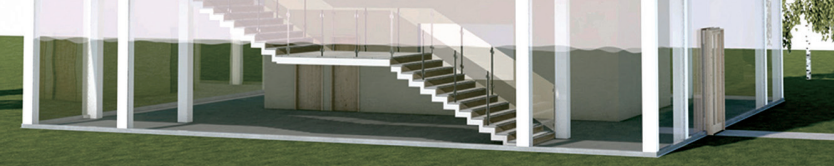

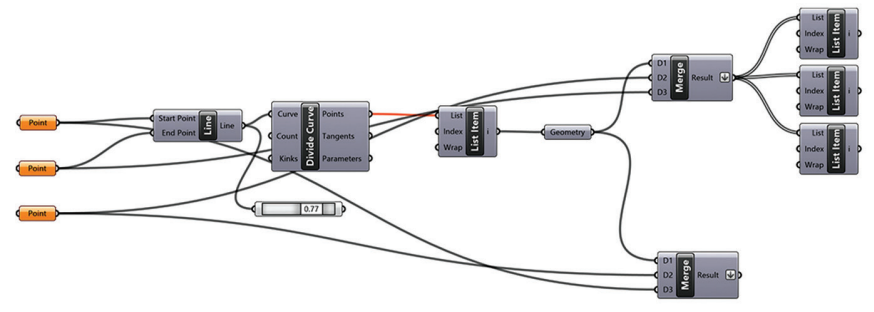

Pawła Sikorskiego obrazuje w głównej mierze zagadnienie form-finding (il. 3-6). Realizacja systemu rozkładającego kształtki elewacyjne (il. 5) polegała na zaprojektowani algorytmu wypełniajacego matrycę możliwych połączen. Przykład ten dodatkowo wykorzystuje język programowania Processing do skonstruowania układu kształtek. Parametry w postaci rodzaju ksztattki i częstotliwości jej wystepowani generowały serię różnorodnych układów (il. 4). Środowisko Grasshopper zostato wykorzystane na dwa sposoby. Pierwszy skrypt generuje bryly kstaltek, a nastepnie prenosi szy skrypt gen ju brich DDL (ele przez sick wion kśtantek po przez zming noszczegól nych parametrow, jak fóm

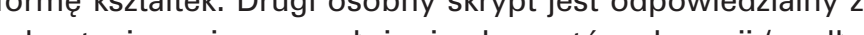
odczytanie zapisanego ułożenia elementow elewacji (według wyników algorytmu z programu Processing i rozmieszczenie odpowiednich kształtek na płaszczyznie elewacji (il. 6). Środowisko ARCHICADA słuzy do wizualnego zaprezentowani rozwiązania oraz do stworzen dopasowania wygenerowanego rozwiązania do tektoniki budynku i potrzeb projektanta.

\section{Podsumowanie}

Podsumowując warto spojrzeć na te zaawansowane narzędzia projektowe jako odpowiedż, ktora umożliwia aplikacje współczesnej wiedzy do procesu edukacyjno - projektowego. Projektowanie parametryczne, oprócz formowania plastyk elewacji, może zostac wykorzystane do rozwiazzywania złożoII. 9 Ćwiczenie laboratoryjne z przedmiotu Techniki BIM
w projektowaniu (autorka: Klaudia Skiba, prowadzacy za-
jeccia: mgr inż. arch. Rafat Zielininski) Design (Author: Klaudia Skiba, lecturer: MSc. Arch. Rafal
Dil. 9 . Laboratory

represented here by polygon lattices). At this stage it is possible to control the size of the fittings by manipulating respective parameters as well as to separate script was responsible for reading of the saved arrangement of facade elements (according to the results of the algorithm from the program Processing) and collocating the suitable fittings on ChiCAD is used for a visual representation of $A$ solution and to create a documentation and a final djustment of the generated result to the tectonic of the building and the needs of the designer.

6. Summary

To summarise it is worth to see these advanced design tools as a response to the demand of the possibility of application of modern knowledge (c) a vivid facade but also it may serve as a solution for complex issues covering the elements of building physics such as solar radiation or thermal insulaaspects of design can be easily represented using a formalised language. On the contrary it is still difficult to conceptualise a digital model concerning such aspects as aesthetic values or an emotiona response of users. We believe that computation shop if he wants to be familiar with various design methods. Therefore the potential concealed in the advanced use of this type of design should be exposed in architectural education. An imporfuture architects in this direction is the application of a form-finding approach in design. To a certai extent it enforces the replacement of a mass pro- 
